\title{
Effects of 8-Azaguanine, Thiouracil and Ethionine on Floral Initiation and Vegetative Development in Seedlings of Pharbitis Nil Chois.
}

\author{
by Keiji Marushige* and Yasuko Marushige*
}

Received April 16, 1962

In order to investigate biochemical changes involved in flowering, a number of attempts on modifying floral induction by applications of metabolic substrates, inhibitors, plant growth-hormones and others have been made. Recently, a considerable interest has been evoked as to the control of floral initiation by affecting the protein and nucleic acid metabolism ${ }^{1-6)}$. In the present experiments, the effects on floral initiation of 8-azaguanine, thiouracil and ethionine which are known to interfere with the synthesis of nucleic acid and protein have been investigated in Pharbitis seedlings. The effects of the above chemicals on vegetative development of the plumules have also been examined.

Seedlings of Pharbitis Nil Chois., strain Violet, were used. The imbibed seeds were sown in wooden boxes containing sand and germinated at $30^{\circ}$ in darkness. After two days, the seedlings were transferred to continuous illumination given by incandescent lamps combined with daylight fluorescent lamps yielding approximately 3000 lux at the plant level. After 32 hours of the illumination at $30^{\circ}$ which was enough to make the following dark period effective for floral induction, the seedlings were subjected to a single dark period of 14 hours at $26-28^{\circ}$, and then returned to continuous light at $30^{\circ}$. Just before the inductive dark period, solutions of the chemicals were applied to the upper surface of the cotyledons with a writing brush, and gauzes drenched with the solutions were stuck to the lower surface of the cotyledons. Thus, approximately $0.4 \mathrm{~m} l$ of the solutions were applied to a pair of the cotyledons. At the end of such an inductive dark period, the gauzes were removed and the cotyledons were rinsed with tap water.

Two to three weeks after the treatments, plants were carefully dissected for the observation of flower bud initiation under a binocular microscope of low magnification. For the quantitative criteria of flowering response, percentage of flowering plants, percentage of plants with a terminal flower bud, and an average number of flower buds per plant, were used. For determination of the rate of vegetative development, the plumules were clipped from the seedlings 10 days after the treatments, dried in an oven at $100 \pm 5^{\circ}$ to a constant weight, and weighed on a torsion balance. The results obtained are summarized in Table 1.

As shown in the table, nucleic acid-base analogs, i.e., 8-azaguanine and thiouracil, inhibited photoperiodic initiation of flower primordia, and the inhibition was reversed by simultaneous application of the corresponding metabolites. Floral initiation was stimulated slightly by guanine, and considerably by uracil. In the case of the 8azaguanine, the differences were slight but consistent in the several replicated experiments. In this kind of experiments, special regards should be paid to whether the chemicals affected flower differentiation specifically or not. 8-azaguanine had an

\footnotetext{
* Laboratory of Applied Botany, Faculty of Agriculture, Kyoto University, Kyoto, Japan.
} 
discrepant, however, with the present findings. In addition, it was indicated that $5 \times 10^{-4} \mathrm{M}$ ethionine stimulated considerably floral initiation, and this stimulation was completely reversed by simultaneous application of $10^{-3} \mathrm{M}$ methionine, which by itself did not suppress floral induction.

The authors wish to express their deep gratitude to Prof. S. Imamura and Dr. A. Takimoto for their valuable criticism throughout the study.

\section{References}

1) Collins, W. T., and Salisbury, F. B., Plant Physiol. 35: suppl. xxiii (1960). 2) Hess, D., Planta 54: 74 (1959). $\quad$ 3) Hess, D., ibid. 56: 229 (1961). 4) Hess, D., ibid. 57: 13 (1961). 5) Salisbury, F. B., and Bonner. J., Plant Physiol. 35: 173 (1960). 6) Zevaart, J. A. D., ibid. 36: suppl. lii (1961).

摘 要

丸重㤵二・丸重靖子：アサガオの芽ばえに㧤ける花芽形成ならびに栄養生長に及洨す

8-アザグアニン，チオウラシル，エチオニンの影響

アサガオの芽ばえを用い，14 時間暗期間を通じて子葉に与えた 8-アザグアニン，チオウラシル，エチ オニンが，花芽形成ならびに栄養生長に及ぼす影響を調べた。

1. 8-アザグアニン $\left(5 \times 10^{-4} \mathrm{M}\right)$ は，栄盖生長に対して影響を与兄ることなく，特異的に花芽形成を阻 害する。 この阻害は，同時にグアニン $\left(10^{-3} \mathrm{M}\right)$ を与兄ることによって軽減される。グアニン $\left(10^{-3} \mathrm{M}\right)$ 単独では，わずかに花芽形成を促進する。

2. チオウラシル $\left(10^{-3} \mathrm{M}\right)$ は, 花芽形成特よび栄養生長をともに, 著しく阻害するが，これらの阻害 は, 同時に与兄られたウラシル $\left(2 \times 10^{-3} \mathrm{M}\right)$ によって部分的に軽減される。 ウラシル $\left(2 \times 10^{-3} \mathrm{M}\right)$ 単独 では，花芽形成を促進する。

3. 高濃度のエチオニン $\left(5 \times 10^{-3} \mathrm{M}\right)$ は，花芽形成ならびに栄養生長をともに著しく阻害する．同時に 与兄られたメチオニン $\left(10^{-2} \mathrm{M}\right)$ によって, 栄盖生長の阻害は回復するが, 花芽形成阻害はまったく回復 しない，低濃度のエチオニン $\left(5 \times 10^{-4} \mathrm{M}\right)$ は，栄盖生長に対する影響なしに，花芽形成を促進する。この 促進効果は同時に与えられたメチオニン $\left(10^{-3} \mathrm{M}\right)$ によって除去される。高濃度のメチオニン $\left(10^{-2} \mathrm{M}\right)$ は，著しく花芽形成を阻害する。(京都大学農学部応用植物学研究室) 